\title{
Rapid Green synthesis of Nano SiO2 using Bryophyllum pinnatum leaf and evaluation of physicochemical quality attributes
}

\section{Sankareswaran}

Muthayammal College of Arts and Science

\section{Sasivarnam}

Karpagam Academy of Higher Education

\section{A. Anbukumaran}

Urumu Dhahalakshmi College

P. Rajiv ( $\square$ rajivsmart15@gmail.com )

Karpagam Academy of Higher Education

\section{Sugapriya Dhanasekaran}

University of Bisha

Mosleh Mohammad Abomughaidv

University of Bisha

\section{Short Report}

Keywords: Silica nanoparticles, Bryophyllum pinnatum, Green synthesis, seed germination

Posted Date: December 17th, 2021

DOI: https://doi.org/10.21203/rs.3.rs-1144662/v1

License: (9) (i) This work is licensed under a Creative Commons Attribution 4.0 International License. Read Full License 


\section{Abstract}

The present study focused on determining the phytochemical analysis of the possible chemical groups present in leaves extract, green synthesis, its characterization, and applications. Bryophyllum pinnatum leaf extract was used to synthesized the Silica nanoparticles. Green synthesized nanoparticles were characterized by different techniques such as UV-Visible absorbance spectroscopy, Fourier Transform Infra-Red, X-Ray Diffraction, Scanning Electron Microscope, Energy Dispersive X-Ray, Zeta Potential Analysis and Thermo-Gravimetric Analysis. A UV-Visible spectrum of silica nanoparticles displayed an absorption peak at $280 \mathrm{~nm}$, and FT-IR results highlighted the key bioactive compounds that could be responsible for capping and reduction of Silica nanoparticles. The XRD pattern analysis showed its crystalline nature and an average size is $24 \mathrm{~nm}$. SEM analysis revealed that synthesized nanomaterials are spherical in shape. Silica nanoparticles showed excellent stability with negative zeta potential value $(-32 \mathrm{mV})$ and uniform dispersion in aqueous media. Moreover, the seed germination assay was carried out on Vigna radiata using the biogenic silica nanoparticles. The low concentration of silica nanoparticles was enhancing the seed germination. Meanwhile, the higher concentration of the silica nanoparticles decreased seed germination and shoot and root formation. Silica nanoparticles at optimum concentration could be used in the agriculture field as nano growth promoters.

\section{Introduction}

The field of nanoscience and nanotechnology has the potential for revolutionizing the methods to create the novel materials. It will give the significant impact on biological sciences and increase its values exponentially in the future (Kumar and Kumbhat, 2016; Hulla et al., 2015). These unique nanomaterials have wide-ranging physicochemical properties and are extensively used in food packaging industries, agricultural industries, biosensors, biomedical, textile and environmental applications (Hulla et al., 2015; Nguyen et al., 2018).

Among all the available nanoparticles, inorganic mesoporous silica nanoparticles are the newcomers to the field, contributing with their unique physical and chemical properties and excellent properties (small size, strong surface energy, high scattered performance, and thermal resistance) (Ma et al., 2013; Wang et al., 2015). Silica nanoparticles have numerous applications, including drug delivery, biosensing, catalysis, bioimaging, and energy storage (Nandanwar et al., 2013; Kordasht et al., 2020). Silicon plays a vital role in increasing plant tolerance against pests and diseases. Mesoporous silica nanoparticles were used as a solid adsorbent for the removal of lindane pesticides from aqueous solutions (El-Said et al., 2018). The synthesis, properties, and applications of silica nanoparticles have become a quickly expanding field of research (Nandanwar et al., 2013). The silica nanoparticles have been produced from agricultural wastes (Adebisi et al., 2019). Stober process is used for the preparation of monodispersed silica colloids 'white carbon black" by hydrolysis of alkyl silicates and silicic acid in alcoholic solutions using ammonia as catalyst (Ibrahim and Zikry et al., 2010). 
Synthesis of metal/metal oxides nanomaterials, hybrid materials, and bioinspired materials using plants and microbes/other natural resources has received significant attention as a reliable, sustainable, costeffective and an eco-friendly technology in nanoscience alternative to chemical and physical methods (Singh et al., 2018; Parveen et al., 2016).

Bryophyllum pinnatum (Figure 1) is commonly known as Pattharcatta. It belongs to Crassulaceae family. The herb contains a wide range of valuable chemicals that could be responsible for its various pharmacological effects (Latif et al., 2019). It is mainly used as a natural anti-inflammatory agent (Fernandes et al., 2019). It is used in ethnomedicinal practices to treat kidney stones, jaundice, skin diseases, hypertension, and urinary problems (Oufir et al., 2015; Yadav et al., 2016). The leaves of $B$. pinnatum possess both sedative and muscle relaxant properties (Von Manitiuset al., 2019)

This study focused on the green synthesis of silica nanoparticles using an aqueous extract of $B$. pinnatum by sustainable approach, simple, cheap, and environmentally friendly manner. In addition, the current research aimed to investigate the effect of silica nanoparticles on seed germination of Vigna radiata and its development of root and shoot after the germination.

\section{Materials And Methods}

The analytical grade chemicals and reagents were used in the experimental studies. Tetra Ethyl Ortho Silicate (TEOS), Hydrochloric acid, Ethanol and Double distilled water (DDW) were obtained for this investigation. All the glasswares were soaked in acids and washed with distilled water.

\subsection{PREPARATION OF PLANT EXTRACT AND PHYTOCHEMICAL SCREENING}

Fresh and healthy leaves were collected from villages of south Coimbatore (District), Tamilnadu, India, on January 2021. The leaves were cleaned with running tap water to remove debris and other organic contents. The aqueous extract was made by mixing and macerating 10 grams of fresh $B$. pinnatum leaves with $200 \mathrm{ml}$ of double-distilled water. The mixture was boiled for 20 minutes at $50^{\circ} \mathrm{C}$. The extract was cooled down and filtered by Whatman filter paper, and the extract was stored at $4^{\circ} \mathrm{C}$ for further analysis. The phytochemicals of $B$. pinnatum were screened by the methods of Harborne (1998).

\subsection{SYNTHESIS OF SILICA NANOPARTICLES}

Tetra Ethyl Ortho Silicate (TEOS) is a precursor for the production of silica nanoparticles. $20 \mathrm{~mL}$ of plant extract was mixed with $12 \mathrm{~mL}$ of precursor solution and allowed continuous stirring at 50 to $65 \circ \mathrm{C}$ for 10 min. Then, $1 \mathrm{M} \mathrm{HCL}$ was mixed on the above mixture. After $20 \mathrm{~min}$, jelly-like precipitation was formed. Next, the precipitation was dried in a hot air oven. Finally, the white color power was obtained and stored in a sterile air tight container for further analysis. 


\subsection{CHARACTERIZATION OF SYNTHESIZED SILICA NANOPARTICLES}

Various techniques were used to characterize the synthesized biogenic silica nanoparticles. The optical property of biogenic silica nanoparticles was determined by the UV-Visible Double beam spectrophotometer. The nature of biogenic silica nanoparticles was determined by the X-ray diffractometer. The atomic percentage of elements present in the biogenic silica nanomaterials was determined by EDX. The surface morphology of silica nanoparticles was assessed by the SEM analysis. The functional group of silica nanoparticles and aqueous plant extract were identified by the FT-IR spectrometer. The charge of silica nanoparticles was determined using a Malvern particle size analyzer. Thermal stability of synthesized silica nanoparticles was analyzed by Mettle-Toledo TGA.

\subsection{SEED GERMINATION ANALYSIS}

Seeds of Vigna radiata were used for this investigation. Four different concentrations $(25,50,75$, and 100 $\mu \mathrm{g} / \mathrm{mL}$ ) of silica nanoparticles were prepared using distilled water. The seeds were surface sterilized using $\mathrm{HgCl} 2$ and distilled water. Meantime, the sterile Petri plates were taken, and cotton was placed on them. Then, the 15 seeds were placed on respective plates. A $15 \mathrm{~mL}$ of biogenic silica nanoparticles at various concentrations was poured on seeds in corresponding plates. Positive control (distilled water) was maintained. Next, the plates with seeds were incubated in the dark condition at $37 \circ \mathrm{C}$ for five days. After incubation, the germinated seeds were counted, and the root and shoot length were measured. Five replications were used for this analysis.

\section{Results And Discussion \\ 3.1. PHYTOCHEMICAL ANALYSIS}

Table 1 determined the phytochemicals analysis of $B$. pinnatum (aqueous extract). The steroids, alkaloids, flavonoids, tannins, saponins, and reducing sugar were found in B. pinnatum leaf extract. Terpenoids and Glycosides were absent in the extract. Kavit et al., (2013) reported the medicinally active phytoconstituents like tannins, alkaloids, terpenoids, steroids, and saponins in the leaves of Phyllanthus fraternus. 
Table 1

Screening of phytochemicals in $B$. pinnatum extract.

\begin{tabular}{|c|c|c|c|}
\hline S.No & Qualitative test & Colour Obtained & Aqueous extract (B. pinnatum) \\
\hline 1. & Steroids & Blue green & Presence \\
\hline 2. & Alkaloids & Orange to Red & Presence \\
\hline 3. & Flavonoids & Yellow & Presence \\
\hline 4. & Terpenoids & Red, Pink or Violet & Absence \\
\hline 5. & Tannins & White precipitate & Presence \\
\hline 6. & Saponins & Foam formation & Presence \\
\hline 7. & Glycosides & Blue or Green & Absence \\
\hline 8. & Reducing sugar & Yellow to Orange & Presence \\
\hline
\end{tabular}

UV-Visible absorbance spectroscopy is broadly being utilized as a technique to determine the optical properties of nanosized particles. The result obtained from the analysis of UV-Visible spectroscopy of the sample is presented in Figure 2. The silica nanoparticles formation was confirmed by the peak occurrence in the range between 230 to $300 \mathrm{~nm}$. to Winardi et al., (2020) were analysis the optical properties of silica-coated zinc oxide nanoparticles using the UV-Visible spectroscopy and obtained peaks between the wavelength range of 280 to $400 \mathrm{~nm}$ in UV spectra.

\subsubsection{X-RAY DIFFRACTION (XRD)}

The crystallinity of biogenic silica nanoparticles was evaluated from the X-Ray Diffraction pattern. The most substantial peaks at 2theta values of 22.01 correspond to the crystalline nature silica nanoparticles and are shown in Figure 3. The average size of the silica nanoparticles was calculated by DebyeScherrer's formula. The size of the Bryophyllum pinnatum leaf extract mediated silica nanoparticles is 24 $\mathrm{nm}$. Mohd et al., (2017) carried out the XRD analysis to find out the crystalline nature and size of the sugarcane bagasse mediated nanomaterials.

\subsubsection{ENERGY DISPERSIVE X-RAY DIFFRACTION (EDAX)}

The elemental composition and purity of Bryophyllum pinnatum leaf extract mediated silica nanoparticles were determined by the EDAX analysis. Figure 4 shows the EDAX spectrum for phyto-genic mediated silica nanoparticles. The atomic percentages of carbon (21.68\%), oxygen $(50.95 \%)$, and silica $(27.37 \%)$ were present in green synthesized silica nanoparticles. The carbon was derived from plant 
extract. The silica nanoparticles were synthesized by Dubey et al., (2021), and they assessed the level of its composition. They reported the presence of silica and oxygen with no impurities.

\subsubsection{SCANNING ELECTRON MICROSCOPE (SEM)}

The shape or morphology of the synthesized silica nanoparticles was determined by the SEM analysis. The microscopic images of Bryophyllum pinnatum leaf extract mediated silica nanoparticles are presented in Figure 5 and clearly show the distribution and spherical shape of the silica nanoparticles. Adebisi et al., (2020) reported the production of biogenic silica nanoparticles using maize stalk and determined its morphology using the SEM analysis.

\subsubsection{FOURIER TRANSFORM INFRARED SPECTROSCOPY (FT-IR)}

FT-IR spectra of plant extract and silica nanoparticles are shown in Figures $6 a$ and $b$. The peaks such as $3348,2970,2885,1921,1658,1442,1087,879,671$, and $555 \mathrm{~cm}-1$ are in Figure $4 \mathrm{a}$ and correspond to the hydroxyl, amide, and carboxyl functional groups. The spectrum of silica nanoparticles shows the peaks such as $2978,2893,1589,1396,1143,1072,956,678$, and $555 \mathrm{~cm}-1$. The nanomaterials spectrum has metal oxide functional groups and hydroxyl, amide, and carboxyl functional groups. FT-IR study was determined the functional groups of capping, reducing, and stabilizing agents from Bryophyllum pinnatum leaf extract to form the nanomaterials. Anuar et al., (2020) were found the functional groups or chemical groups, namely $\mathrm{Si}-\mathrm{O}-\mathrm{Si}, \mathrm{CH} 2,-\mathrm{OH}$, and $\mathrm{Si}-\mathrm{OH}$ form the FT-IR spectrum of coconut husk ash mediated silica nanomaterials.

\subsubsection{ZETA POTENTIAL MEASUREMENT}

Zeta potential analysis is a traditional method to determine the stability of the nanomaterials. The silica nanoparticles from B. pinnatum show negative charges and the zeta potential value of $-32.4 \mathrm{mV}$ (Figure 7). The high value of zeta potential refers to the stability of the suspension due to the increased force of electrostatic repulsion between the particles. The low zeta potential value indicates the aggregation of the nanomaterials (Wang et al., 2010). The silica nanoparticles with antibacterial properties were produced by Joni et al., (2020). In addition, they reported the zeta potential value of $-24.69 \mathrm{mV}$ for the silica nanoparticles.

\subsubsection{Analysis of Thermal stability}

Thermal stability of synthesized silica nanoparticles was performed to determine the weight loss of green synthesize silica nanoparticles at different temperatures (the range between 30 to $1000^{\circ} \mathrm{C}$ ) (Figure 8). The $50 \%$ of weight loss was occurs at $150^{\circ} \mathrm{C}$ because to removal of water molecules and degradation of volatile compounds on surface of as-synthesized silica nanoparticles. 


\subsection{SEED GERMINATION}

Different concentrations $(5,10,15$, and $20 \mu \mathrm{g} / \mathrm{mL})$ of silica nanoparticles were used in the present investigation. The maximum level (100\%) of seed germination was achieved on $5 \mu \mathrm{g} / \mathrm{mL}$ silica nanoparticles treated treatment, and meanwhile, the minimum level (40\%) of seed germination was observed on $20 \mu \mathrm{g} / \mathrm{mL}$ of silica nanoparticles treated treatment. The increased shoot length of $4.3 \mathrm{~cm}$ was observed on the treatment of $5 \mu \mathrm{g} / \mathrm{mL}$ silica nanoparticles, and decreased shoot length of $1.8 \mathrm{~cm}$ was achieved with a concentration of $20 \mu \mathrm{g} / \mathrm{mL}$ of silica nanoparticles. The highest root length $(1.0 \mathrm{~cm})$ was observed on T2 treatment ( $5 \mu \mathrm{g} / \mathrm{mL}$ of Silica nanoparticles), and the lowest root length $(0.2 \mathrm{~cm})$ was recorded on T4 treatment ( $20 \mu \mathrm{g} / \mathrm{mL}$ of silica nanoparticles) (Table 2). Results showed that silica nanoparticles have a significant effect on seed germination, the length of the shoot, and the root. Roohizadeh et al., (2015) observed that silica nanoparticles improved the seed germination on Vicia faba.

Table 2

Analysis of seed germination, root and shoot length on Silica nanoparticles treated Vigna radiata.

\begin{tabular}{|lllll|}
\hline S.No & Concentrations & \% of seed germination & Shoot length $(\mathbf{c m})$ & Root length $(\mathbf{c m})$ \\
\hline 1 & Control - Distilled water & $100 \%$ & $4.0 \pm 0.1$ & $1.0 \pm 0.2$ \\
\hline 2 & $\mathrm{~T} 1-5 \mu \mathrm{g} / \mathrm{mL}$ & $100 \%$ & $4.3 \pm 0.1$ & $1.5 \pm 0.1$ \\
\hline 3 & $\mathrm{~T} 2-10 \mu \mathrm{g} / \mathrm{mL}$ & $70 \%$ & $3.4 \pm 0.2$ & $0.8 \pm 0.1$ \\
\hline 4 & $\mathrm{~T} 3-15 \mu \mathrm{g} / \mathrm{mL}$ & $50 \%$ & $2.0 \pm 0.3$ & $0.5 \pm 0.1$ \\
\hline 5 & $\mathrm{~T} 4-20 \mu \mathrm{g} / \mathrm{mL}$ & $40 \%$ & $1.8 \pm 0.1$ & $0.2 \pm 0.1$ \\
\hline
\end{tabular}

\section{Conclusion}

The aqueous extract of Bryophyllum pinnatum leaf has been used as capping and reducing agents for the green synthesis of silica nanoparticles. The phyto-bioactive like steroids, alkaloids, flavonoids, tannins, saponins, and glycosides were present in leaf extract, confirming the phytochemical analysis. Bio-synthesized silica nanomaterials were characterized by various techniques. Spherical-shaped biogenic silica nanoparticles were produced with an average size of $24 \mathrm{~nm}$. The green synthesized silica nanoparticles enhanced seed germination, shoot, and root formation at low concentration levels. So, Silica nanoparticles could be used to improve seed germination and crop production in agriculture areas.

\section{Declarations}

\section{ACKNOWLEDGEMENT}

The authors thankfully acknowledge the Karpagam Academy of Higher Education for provided the laboratory facilities to conduct the experiments and also the author acknowledge the DST-FIST fund for infrastructure facility (SR/FST/LS-1/2018/187). 


\section{DECLARATION OF INTERESTS}

$\nabla$ The authors declare that they have no known competing financial interests or personal relationships that could have appeared to influence the work reported in this paper.

*Ethics approval - Not applicable

* Consent to participate - Not applicable

* Consent for publication - Not applicable

* Availability of data and materials - Not applicable

* Competing interests

The authors declare that they have no known competing financial interests or personal relationships that could have appeared to influence the work reported in this paper.

Funding

The authors have no relevant financial or non-financial interests to disclose.

* Authors' contributions

SN: Conceptualization

SM: Investigation

AA: Methodology

PR: Supervision, Funding acquisition and Project administration

SD: Data Curation and Writing- Original draft preparation

MMA: Data Curation and Writing- Original draft preparation

* Acknowledgements

The authors thankfully acknowledge the Karpagam Academy of Higher Education for provided the laboratory facilities to conduct the experiments and also the author acknowledge the DST-FIST fund for infrastructure facility (SR/FST/LS-1/2018/187).

* Authors' information (optional). - Not applicable

Please include the sub-sections below of Compliance with Ethical Standards section. - Not applicable

* Disclosure of potential conflicts of interest - Not applicable 
* Research involving Human Participants and/or Animals - Not applicable

* Informed consent - Not applicable

\section{References}

Adebisi, J.A., Agunsoye, J.O., Bello, S.A., Haris, M., Ramakokovhu, M.M., Daramola, M.O. and Hassan, S.B., 2019. Green production of silica nanoparticles from maize stalk. Particulate Science and Technology.

Adumeau, L., Genevois, C., Roudier, L., Schatz, C., Couillaud, F. and Mornet, S., 2017. Impact of surface grafting density of PEG macromolecules on dually fluorescent silica nanoparticles used for the in vivo imaging of subcutaneous tumors. Biochimica et Biophysica Acta (BBA)-General Subjects, 1861(6), pp.1587-1596.

Agarwal, S.K., Bhattacharyya, S.K., Sharma, U. and Ahalawat, S., 2011. Preparation of silica nanoparticles and its beneficial role in cementitious materials. Nanomaterials and Nanotechnology, 1, p.9.

Ahmed, S., Saifullah, Ahmad, M., Swami, B.L. and Ikram, S., 2016. Green synthesis of silver nanoparticles using Azadirachta indica aqueous leaf extract. Journal of radiation research and applied sciences, 9(1), pp.1-7.

Alagesan, V. and Venugopal, S., 2019. Green synthesis of selenium nanoparticle using leaves extract of withania somnifera and its biological applications and photocatalytic activities. Bionanoscience, 9(1), pp.105-116

Anuar, M.F., Fen, Y.W., Zaid, M.H.M., Matori, K.A. and Khaidir, R.E.M., 2020. The Physical and Optical Studies of Crystalline Silica Derived from the Green Synthesis of Coconut Husk Ash. Applied Sciences, 10(6), p.2128.

Chaudhuri, S.K., Chandela, S. and Malodia, L., 2016. Plant Mediated Green Synthesis of Silver Nanoparticles Using Tecomella undulata Leaf Extract and Their Characterization. Nano Biomedicine \& Engineering, 8(1).

Dubey, R.S., Rajesh, Y.B.R.D. and More, M.A., 2015. Synthesis and characterization of SiO2 nanoparticles via sol-gel method for industrial applications. Materials Today: Proceedings, 2(4-5), pp.3575-3579.

El-Said, W.A., Fouad, D.M., Ali, M.H. and El-Gahami, M.A., 2018. Green synthesis of magnetic mesoporous silica nanocomposite and its adsorptive performance against organochlorine pesticides. International Journal of Environmental Science and Technology, 15(8),pp.1731-1744.

Fernandes, J.M., Cunha, L.M., Azevedo, E.P., Lourenço, E.M., Fernandes-Pedrosa, M.F. and Zucolotto, S.M., 2019. Kalanchoe laciniata and Bryophyllum pinnatum: an updated review about ethnopharmacology, phytochemistry, pharmacology and toxicology. Revista Brasileira de Farmacognosia, 29(4), pp.529-558. 
Gnanasangeetha, D. and SaralaThambavani, D.,. One pot synthesis of zinc oxide nanoparticles via chemical and green method. Res. J. Mater. Sci, 2320, p.6055.

Harborne, J.B. 1998. Textbook of Phytochemical Methods. A Guide to Modern Techniques of Plant Analysis. 5th Edition, Chapman and Hall Ltd, London, 21-72.

Hojjat, S.S. and Hojjat, H., 2015. Effect of nano silver on seed germination and seedling growth in Fenugreek seed. International Journal of Food Engineering, 1(2), pp.106-110.

Hulla, J.E., Sahu, S.C. and Hayes, A.W., 2015. Nanotechnology: History and future. Human \& experimental toxicology, 34(12), pp.1318-1321.

Ibrahim, I.A., Zikry, A.A.F. and Sharaf, M.A., 2010. Preparation of spherical silica nanoparticles: Stober silica. J. Am. Sci, 6(11), pp.985-989.

Ingole, R.D., Thalkari, A.B., Karwa, P.N., Zambare, K.K. and Shinde, P.S., 2020. Bryophyllum pinnatum: A magical herb. Alcohol, 19, p.05.

Jadhao, A.D., Shende, S., Ingle, P., Gade, A., Hajare, S.W. and Ingole, R.S., 2020. Biogenic Synthesis of Zinc Oxide Nanoparticles by Bryophyllum pinnatum and its Acute Oral Toxicity Evaluation in Wistar Rats. IEEE Transactions on NanoBioscience, 19(4), pp.633-639.

Jalill, A., Raghad, D.H., Nuaman, R.S. and Abd, A.N., 2016. Biological synthesis of Titanium Dioxide nanoparticles by Curcuma longa plant extract and study its biological properties. World Scientific News, 49(2), pp.204-222.

Joni, I.M., Vanitha, M., Panatarani, C. and Faizal, F., 2020. Dispersion of amorphous silica nanoparticles via beads milling process and their particle size analysis, hydrophobicity and anti-bacterial activity. Advanced Powder Technology, 31(1), pp.370-380.

Kavit, M., Patel, B.N. and Jain, B.K., 2013. Phytochemical analysis of leaf extract of Phyllanthus fraternus. Research Journal of Recent Sciences ISSN, 2277, p.2502.

Khan, K.A., Wadud, M.A., Hossain, M.A. and Obaydullah, A.K.M., 2018. Electrical performance of PKL (Pathor Kuchi leaf) power. IJARIIE, 4(2), pp.3470-3478.

Khan, M.Z.H., Tareq, F.K., Hossen, M.A. and Roki, M.N.A.M., 2018. Green synthesis and characterization of silver nanoparticles using Coriandrum sativum leaf extract. Journal of Engineering Science and Technology, 13(1), pp.158-166.

Kordasht, H.K., Pazhuhi, M., Pashazadeh-Panahi, P., Hasanzadeh, M. and Shadjou, N., 2020. Multifunctional aptasensors based on mesoporous silica nanoparticles as an efficient platform for bioanalytical applications: Recent advances. TrAC Trends in Analytical Chemistry, 124, p.115778. 
Latif, A., Ashiq, K., Qayyum, M., Ashiq, S., Ali, E. and Anwer, I., 2019. Phytochemical and pharmacological profile of the medicinal herb: Bryophyllum pinnatum. JOURNAL OF ANIMAL AND PLANT SCIENCES, 29(6), pp.1528-1534.

Ma, X., Lee, N.H., Oh, H.J., Hwang, J.S. and Kim, S.J., 2010. Preparation and characterization of silica/polyamide-imide nanocomposite thin films. Nanoscale Research Letters, 5(11), pp.1846-1851.

Mohammadi, A., Daemi, H. and Barikani, M., 2014. Fast removal of malachite green dye using novel superparamagnetic sodium alginate-coated Fe3O4 nanoparticles. International journal of biological macromolecules, 69, pp.447-455.

Mohd, N.K., Wee, N.N.A.N. and Azmi, A.A., 2017, September. Green synthesis of silica nanoparticles using sugarcane bagasse. In AIP conference proceedings (Vol. 1885, No. 1, p. 020123). AIP Publishing LLC.

Nandanwar, R., Singh, P. and Haque, F.Z., 2013. Synthesis and properties of silica nanoparticles by sol-gel method for the application in green chemistry. Material Science Research India, 10(1), pp.85-92.

Nguyen, N.H., Padil, V.V.T., Slaveykova, V.I., Černík, M. and Ševců, A., 2018. Green synthesis of metal and metal oxide nanoparticles and their effect on the unicellular alga Chlamydomonas reinhardtii. Nanoscale research letters, 13(1), pp.1-13.

Ogidi, O.I., Esie, N.G. and Dike, O.G., 2019. Phytochemical, Proximate and Mineral compositions of Bryophyllum pinnatum (Never die) Medicinal plant. Journal of Pharmacognosy and Phytochemistry, 8(1), pp.629-635.

Okaiyeto, K., H. and Okoh, A.I., 2021. Plant-based synthesis of silver nanoparticles using aqueous leaf extract of Salvia officinalis: Characterization and its antiplasmodial activity. Journal of Cluster Science, 32(1), pp.101-109.

Oufir, M., Seiler, C., Gerodetti, M., Gerber, J., Fürer, K., Mennet-von Eiff, M., Elsas, S.M., Brenneisen, R., von Mandach, U., Hamburger, M. and Potterat, O., 2015. Quantification of bufadienolides in Bryophyllum pinnatum leaves and manufactured products by UHPLC-ESIMS/MS. Planta medica, 81(12/13), pp.11901197.

Parveen, K., Banse, V. and Ledwani, L., 2016, April. Green synthesis of nanoparticles: their advantages and disadvantages. In AIP conference proceedings (Vol. 1724, No. 1, p. 020048). AIP Publishing LLC.

Poorakbar, E., Shafiee, A., Saboury, A.A., Rad, B.L., Khoshnevisan, K., Ma'mani, L., Derakhshankhah, H., Ganjali, M.R. and Hosseini, M., 2018. Synthesis of magnetic gold mesoporous silica nanoparticles core shell for cellulase enzyme immobilization: Improvement of enzymatic activity and thermal stability. Process biochemistry, 71, pp.92-100. 
Prajapati, J.P., Das, D., Katlakunta, S., Maramu, N., Ranjan, V. and Mallick, S., 2021. Synthesis and characterization of ultrasmall $\mathrm{Cu}_{2} \mathrm{O}$ nanoparticles on silica nanoparticles surface. Inorganica Chimica Acta, 515, p.120069.

Roohizadeh, G., Majd, A. and Arbabian, S., 2015. The effect of sodium silicate and silica nanoparticles on seed germination and growth in the Vicia faba L. Tropical Plant Research, 2(2), pp.85-89.

Salahdeen, H.M. and Yemitan, O.K., 2006. Neuropharmacological effects of aqueous leaf extract of Bryophyllum pinnatum in mice. African journal of biomedical research, 9(2).

Saraswathi, V.S., Tatsugi, J., Shin, P.K. and Santhakumar, K., 2017. Facile biosynthesis, characterization, and solar assisted photocatalytic effect of ZnO nanoparticles mediated by leaves of L. speciosa. Journal of Photochemistry and Photobiology B: Biology, 167, pp.89-98.

Singh, J., Dutta, T., Kim, K.H., Rawat, M., Samddar, P. and Kumar, P., 2018. 'Green' synthesis of metals and their oxide nanoparticles: applications for environmental remediation. Journal of nanobiotechnology, 16(1), pp.1-24.

Soni, A. and Sosa, S., 2013. Phytochemical analysis and free radical scavenging potential of herbal and medicinal plant extracts. Journal of Pharmacognosy and phytochemistry, 2(4), pp.22-29.

Tantra, R., Schulze, P., \& Quincey, P. (2010). Effect of nanoparticle concentration on zeta-potential measurement results and reproducibility. Particuology, 8(3), 279-285. doi:10.1016/j.partic.2010.01.003

Tatsimo, S.J.N., de Dieu Tamokou, J., Havyarimana, L., Csupor, D., Forgo, P., Hohmann, J., Kuiate, J.R. and Tane, P., 2012. Antimicrobial and antioxidant activity of kaempferol rhamnoside derivatives from Bryophyllum pinnatum. BMC Research notes, 5(1), pp.1-6.

Ullah, A.A., Haque, M.M., Akter, M., Hossain, A., Tamanna, A.N., Hosen, M.M., Kibria, A.F., Khan, M.N.I. and Khan, M.K.A., 2020. Green synthesis of Bryophyllum pinnatum aqueous leaf extract mediated biomolecule capped dilute ferromagnetic a-MnO2 nanoparticles. Materials Research Express, 7(1), p.015088.

Uskokovic, V., 2013. Entering the era of nanoscience: time to be so small. J Biomed Nanotechnol, 9(9), pp.1441-1470.

Von Manitius, S., Flügel, D., Steinlein, B.G., Schnelle, M., von Mandach, U. and Simões-Wüst, A.P., 2019. Bryophyllum pinnatum in the treatment of restless legs syndrome: A case series documented with polysomnography. Clinical case reports, 7(5), p.1012.

Wang, J., Zheng, S., Shao, Y., Liu, J., Xu, Z. and Zhu, D., 2010. Amino-functionalized Fe304@ SiO2 coreshell magnetic nanomaterial as a novel adsorbent for aqueous heavy metals removal. Journal of colloid and interface science, 349(1), pp.293-299. 
Wang, Y., Zhao, Q., Han, N., Bai, L., Li, J., Liu, J., Che, E., Hu, L., Zhang, Q., Jiang, T. and Wang, S., 2015. Mesoporous silica nanoparticles in drug delivery and biomedical applications. Nanomedicine: Nanotechnology, Biology and Medicine, 11(2), pp.313-327.

Winardi, S., Qomariyah, L., Widiyastuti, W., Kusdianto, K., Nurtono, T. and Madhania, S., 2020. The role of electro-sprayed silica-coated zinc oxide nanoparticles to hollow silica nanoparticles for optical devices material and their characterization. Colloids and Surfaces A: Physicochemical and Engineering Aspects, 604, p.125327.

Xu, R., 2008. Progress in nanoparticles characterization: Sizing and zeta potential measurement. Particuology, 6(2), pp.112-115.

Yadav, M., Gulkari, V.D. and Wanjari, M.M., 2016. Bryophyllum pinnatum leaf extracts prevent formation of renal calculi in lithiatic rats. Ancient science of life, 36(2), p.90.

Yadav, R.N.S. and Agarwala, M., 2011. Phytochemical analysis of some medicinal plants. Journal of phytology, 3(12).

\section{Figures}




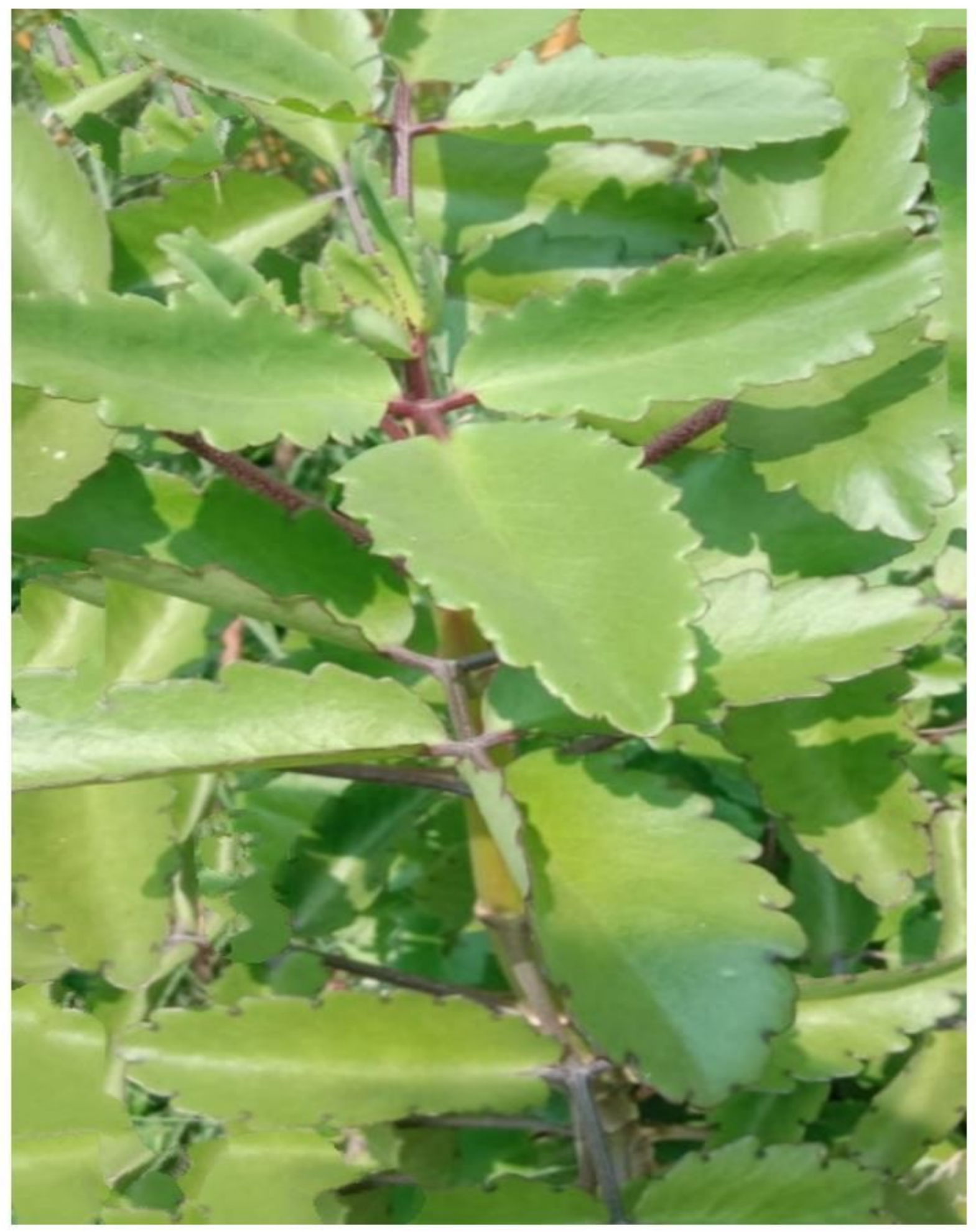

Figure 1

Bryophyllum pinnatum 


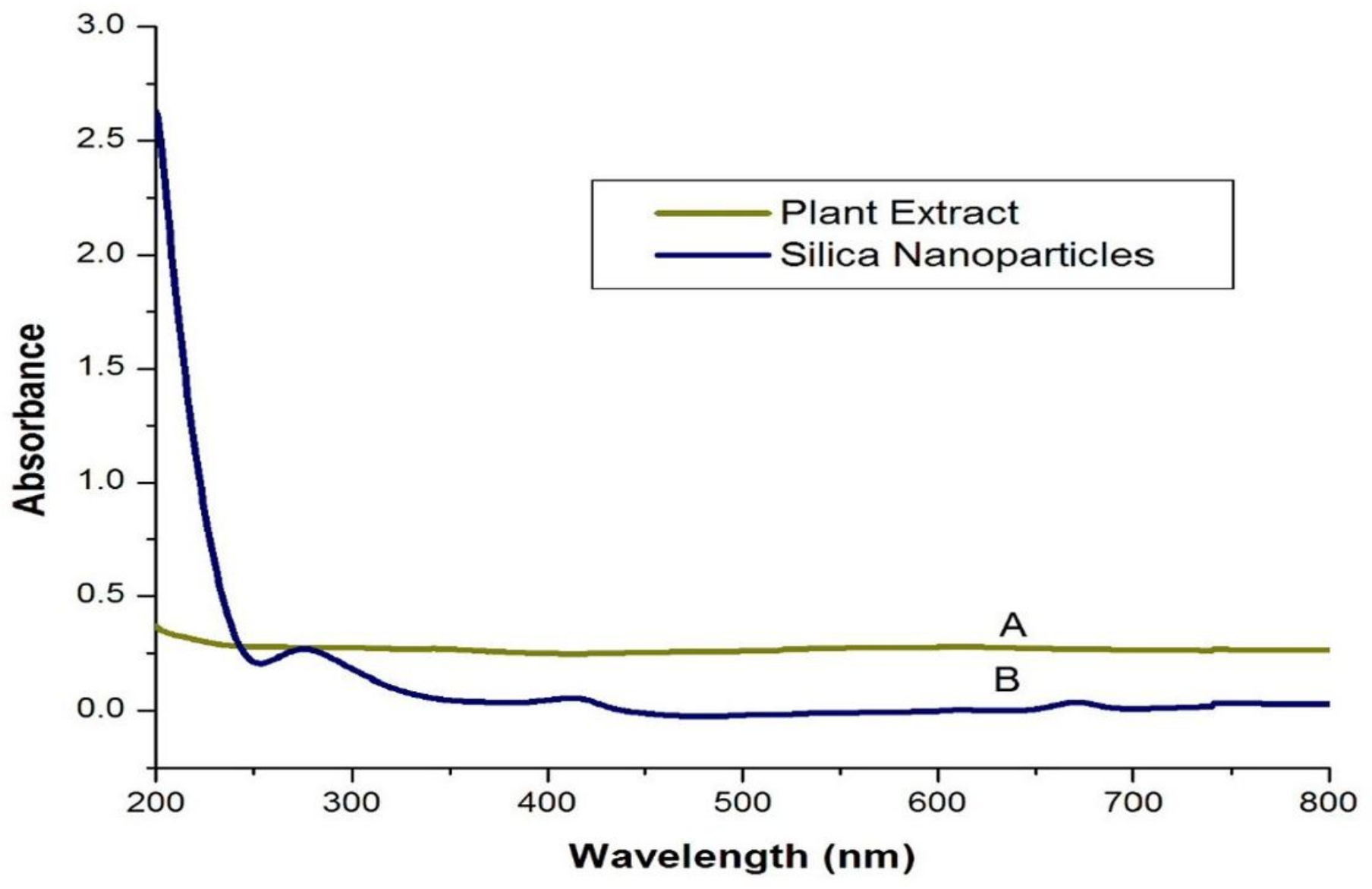

Figure 2

UV spectra of a) plant extract and b) Silica nanoparticles 


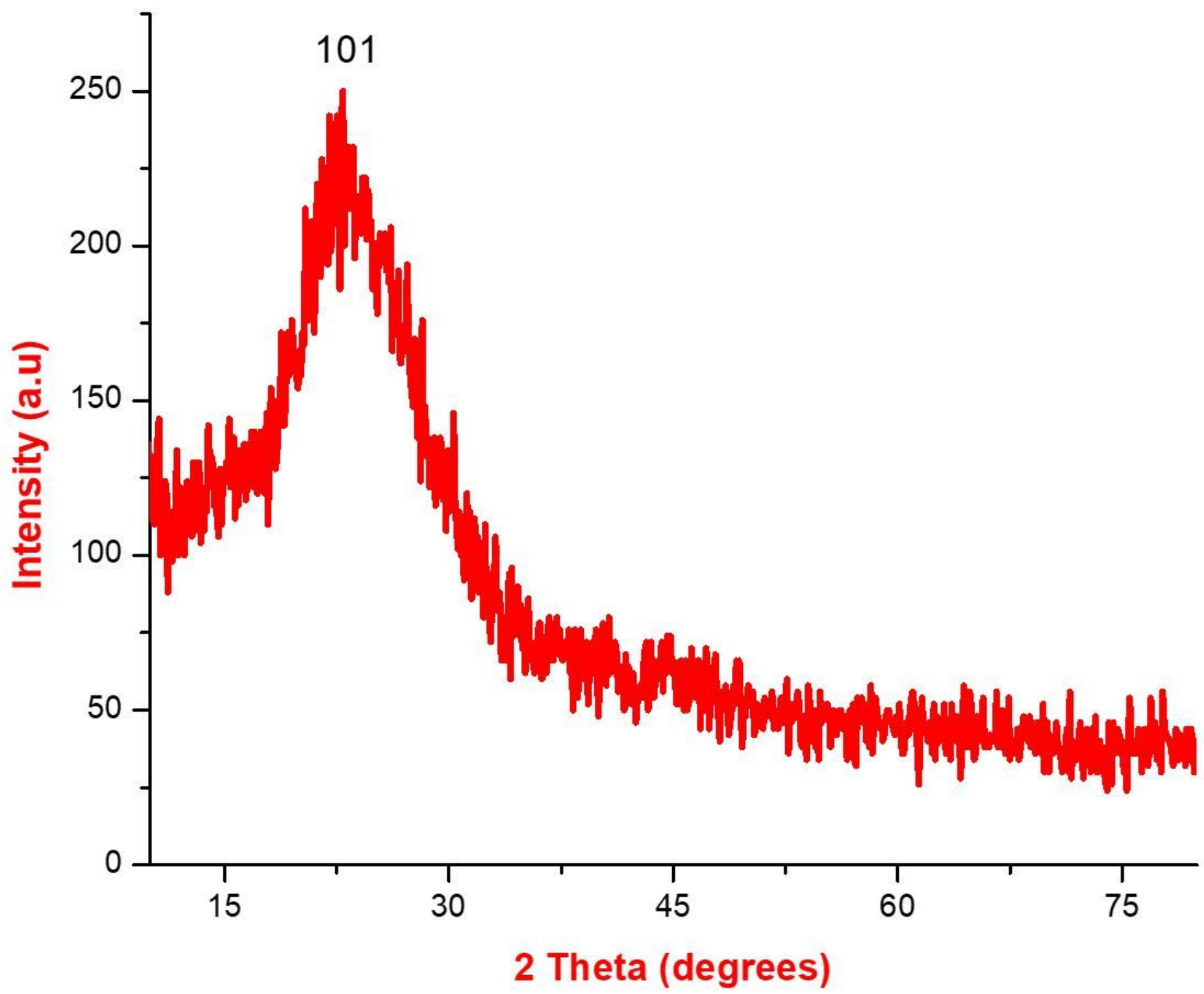

Figure 3

XRD spectrum of Silica nanoparticles 


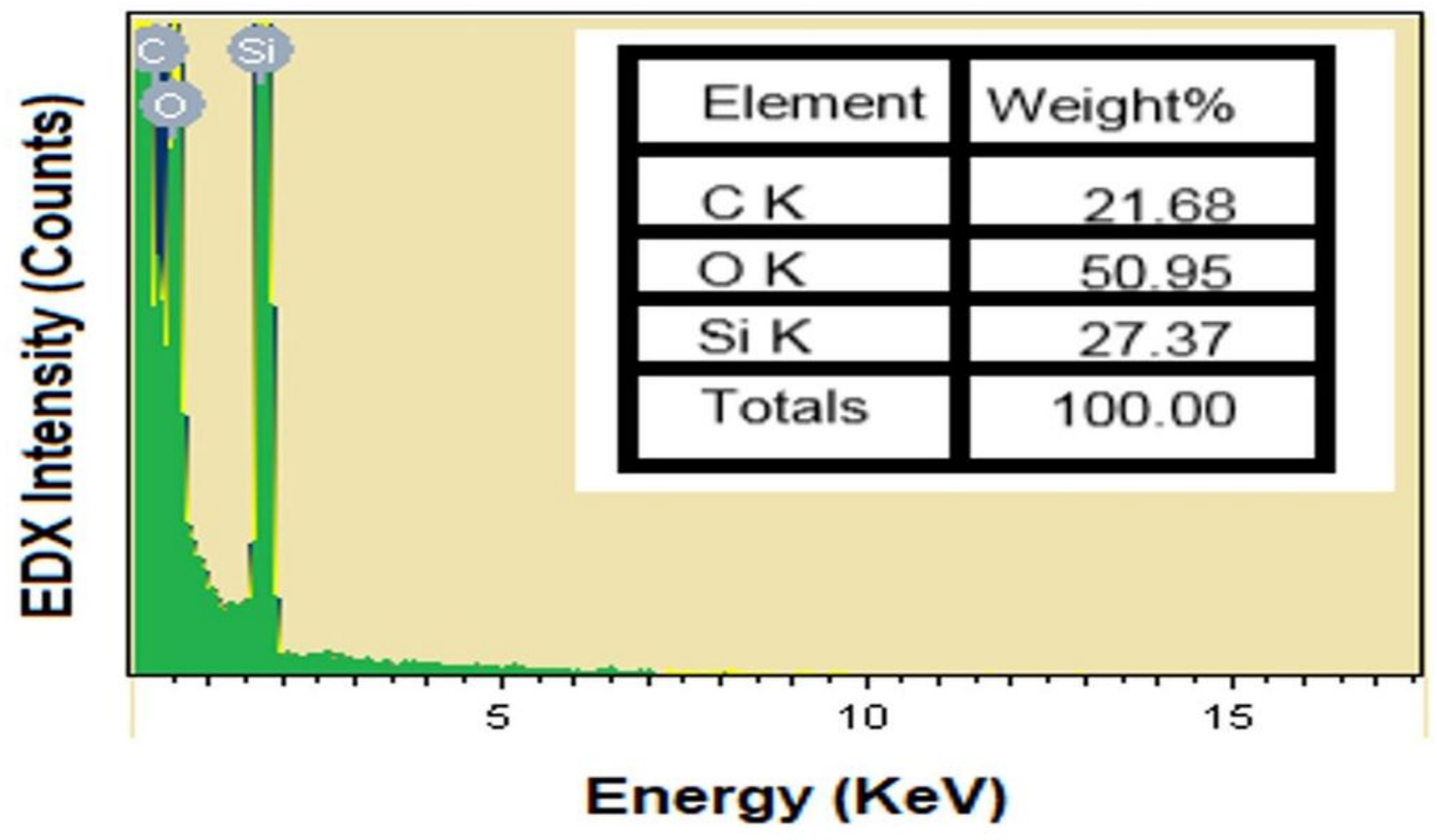

Figure 4

EDX spectrum of Silica nanoparticles
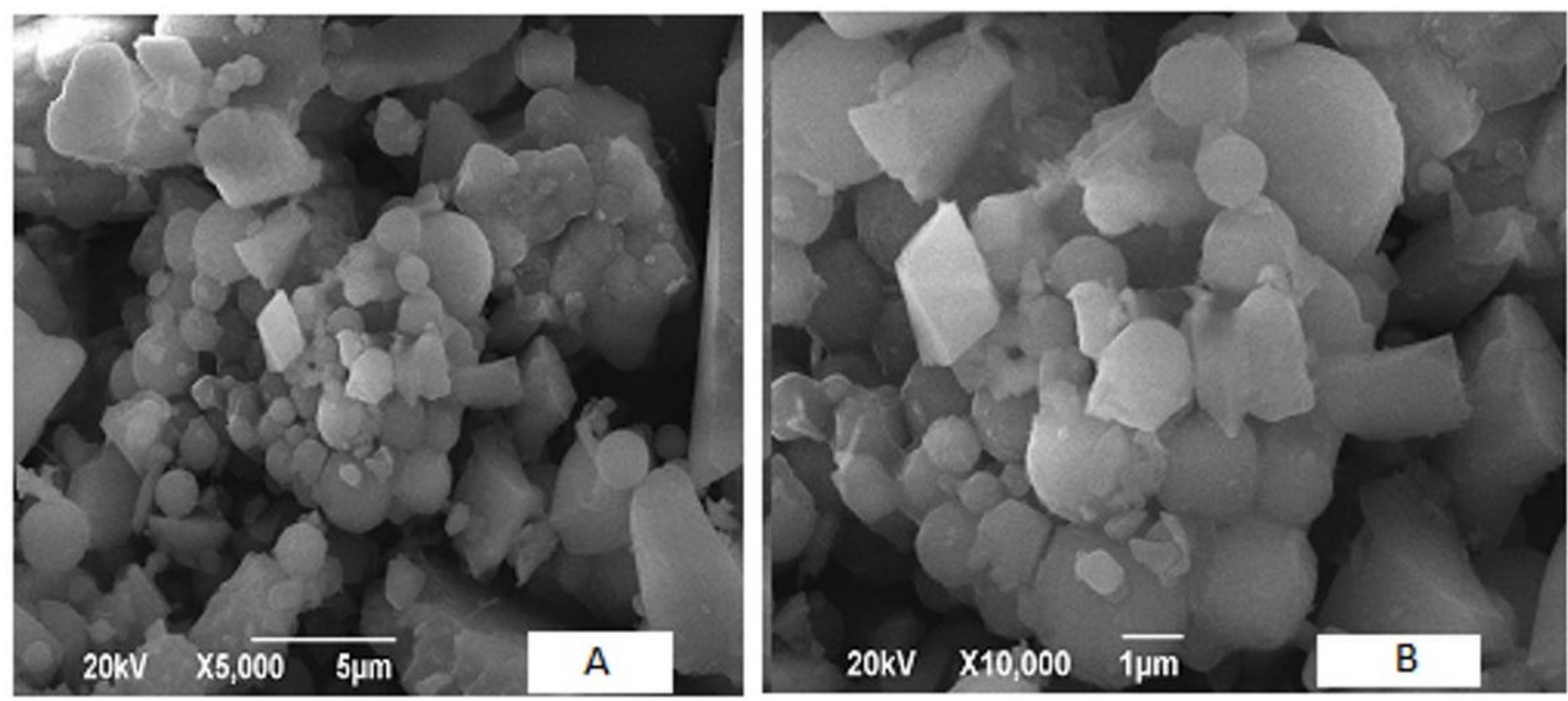

Figure 5

SEM images of Silica nanoparticles 


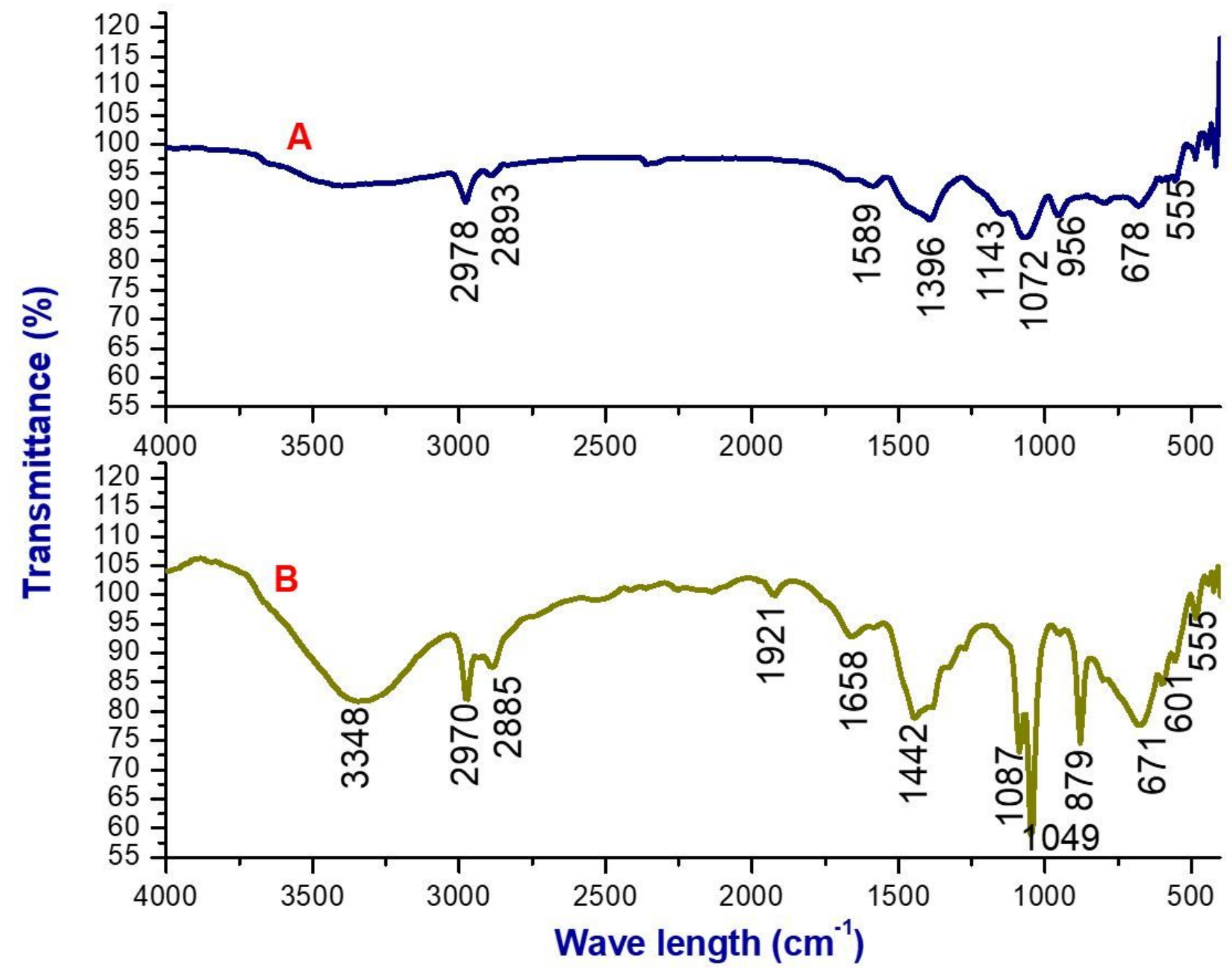

Figure 6

FT-IR spectrum of a) Silica nanoparticles and b) plant extract 


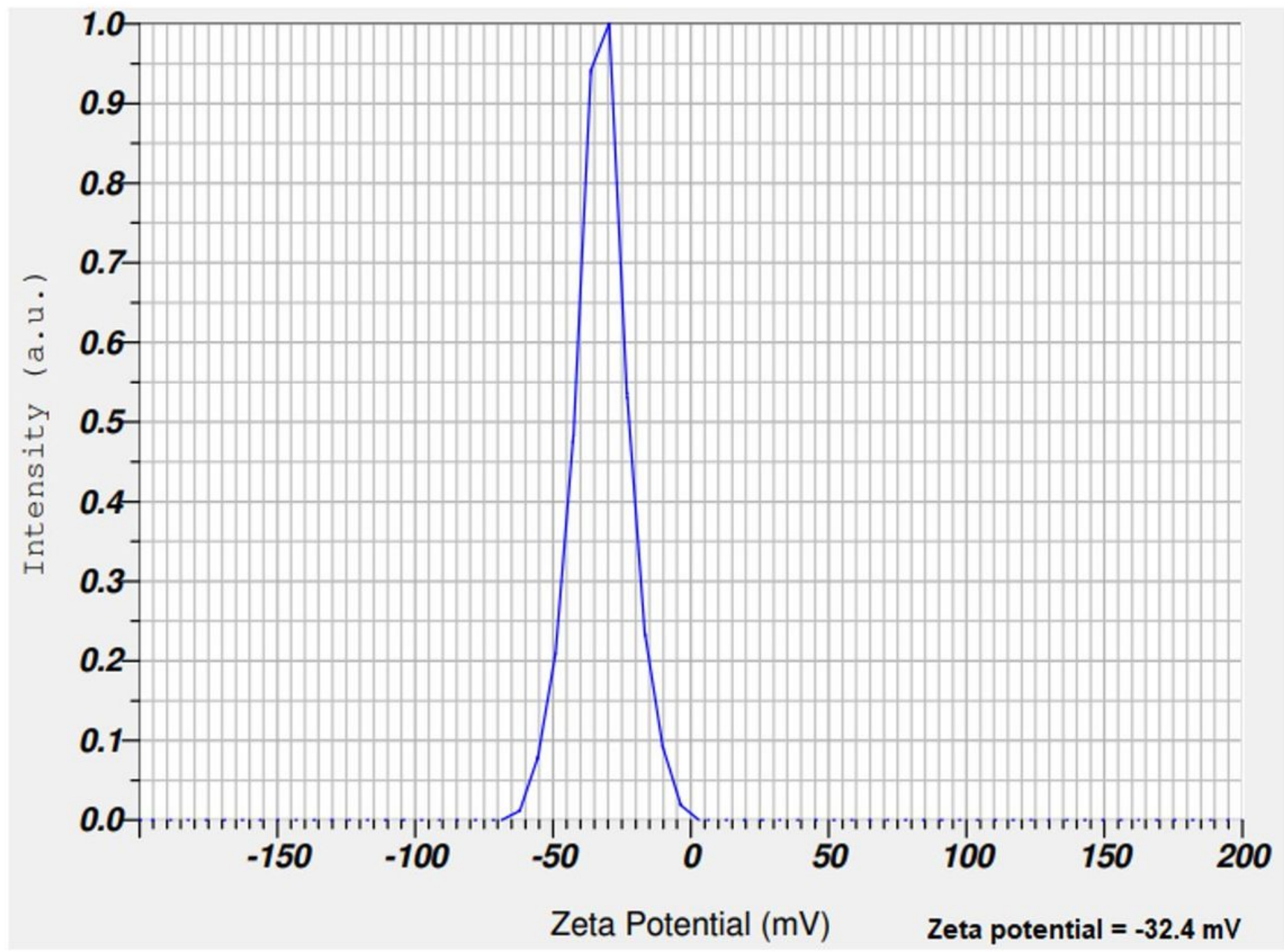

Figure 7

Zeta potential analysis of Silica nanoparticles 


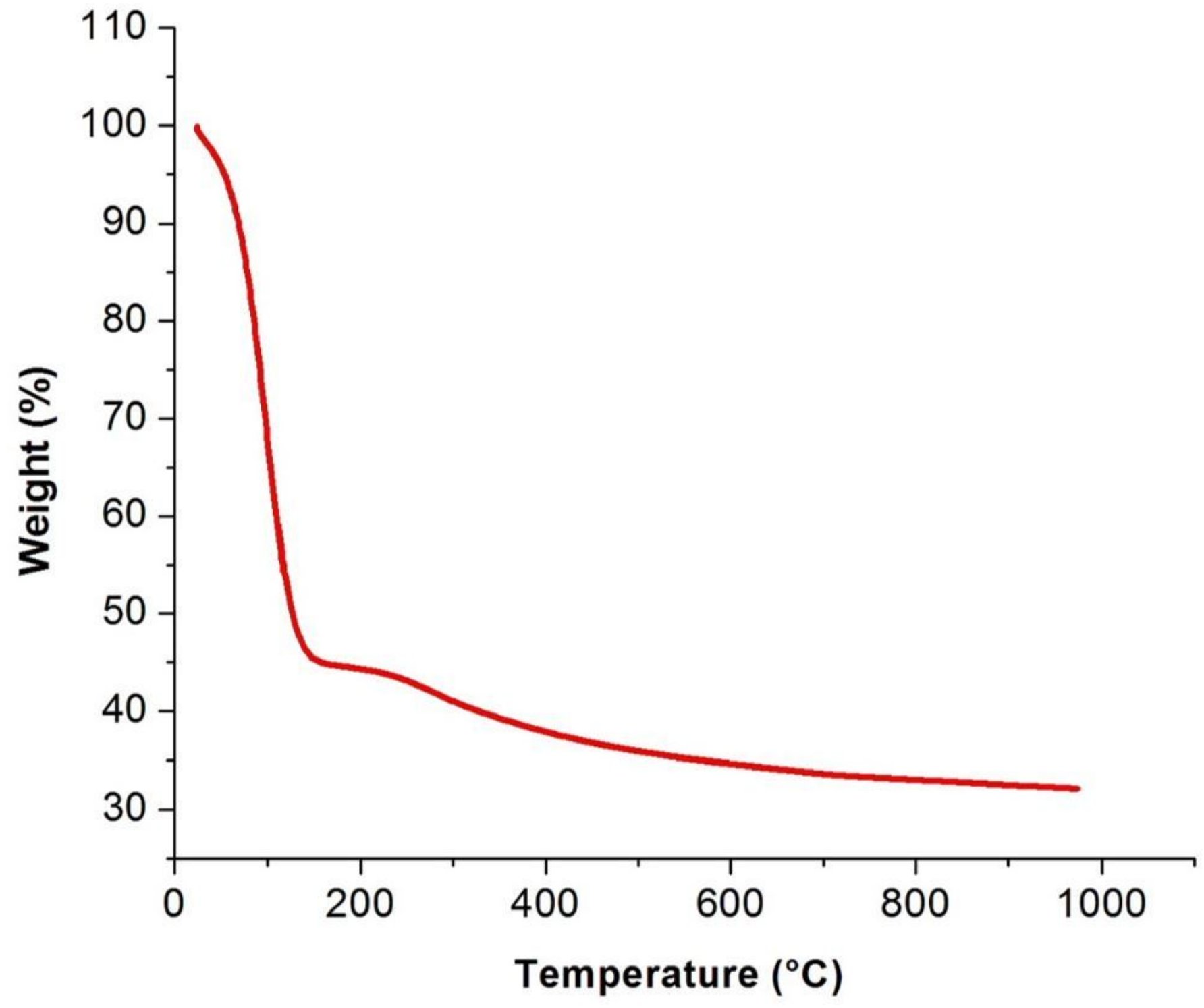

Figure 8

TGA analysis of Silica nanoparticles 